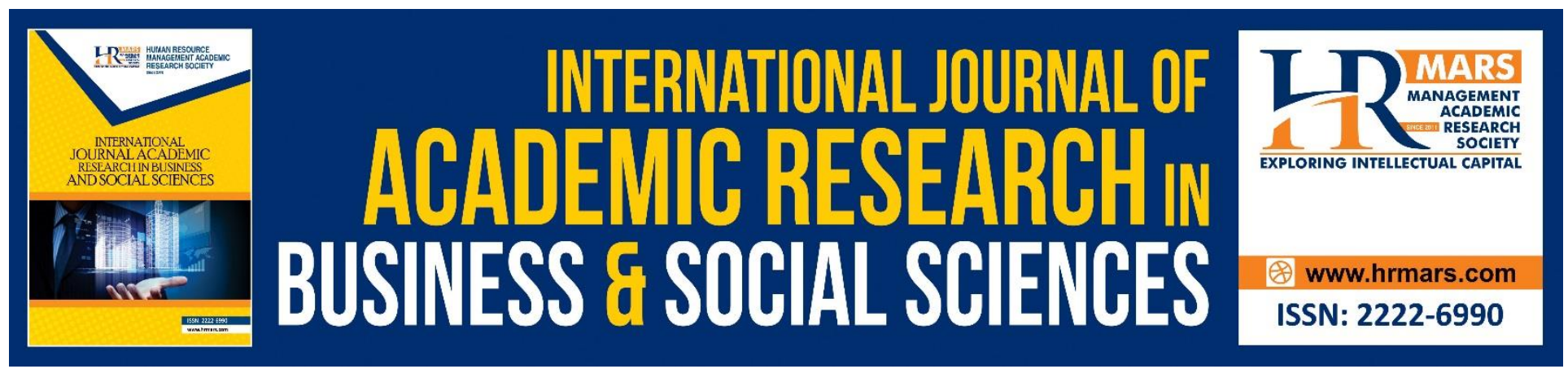

\title{
The Impact of Religiously Motivated Consumer Boycotts on Product Judgment, Brand Image and Loyalty
}

Farhan Mirza, Sarfraz Ashraf, Hafiz Badar Jahangir

To Link this Article: http://dx.doi.org/10.6007/IJARBSS/v10-i11/7902

DOI:10.6007/IJARBSS/v10-i11/7902

Received: 02 September 2020, Revised: 27 September 2020, Accepted: 13 October 2020

Published Online: 14 November 2020

In-Text Citation: (Mirza, Ashraf, \& Jahangir, 2020)

To Cite this Article: Mirza, F., Ashraf, S., \& Jahangir, H. B. (2020). The Impact of Religiously Motivated Consumer Boycotts on Product Judgment, Brand Image and Loyalty. International Journal of Academic Research in Business and Social Sciences. 10(11), 384-402.

Copyright: (C) 2020 The Author(s)

Published by Human Resource Management Academic Research Society (www.hrmars.com)

This article is published under the Creative Commons Attribution (CC BY 4.0) license. Anyone may reproduce, distribute, translate and create derivative works of this article (for both commercial and non-commercial purposes), subject to full attribution to the original publication and authors. The full terms of this license may be seen at: http://creativecommons.org/licences/by/4.0/legalcode

\section{Vol. 10, No. 11, 2020, Pg. 384 - 402}

Full Terms \& Conditions of access and use can be found at http://hrmars.com/index.php/pages/detail/publication-ethics 


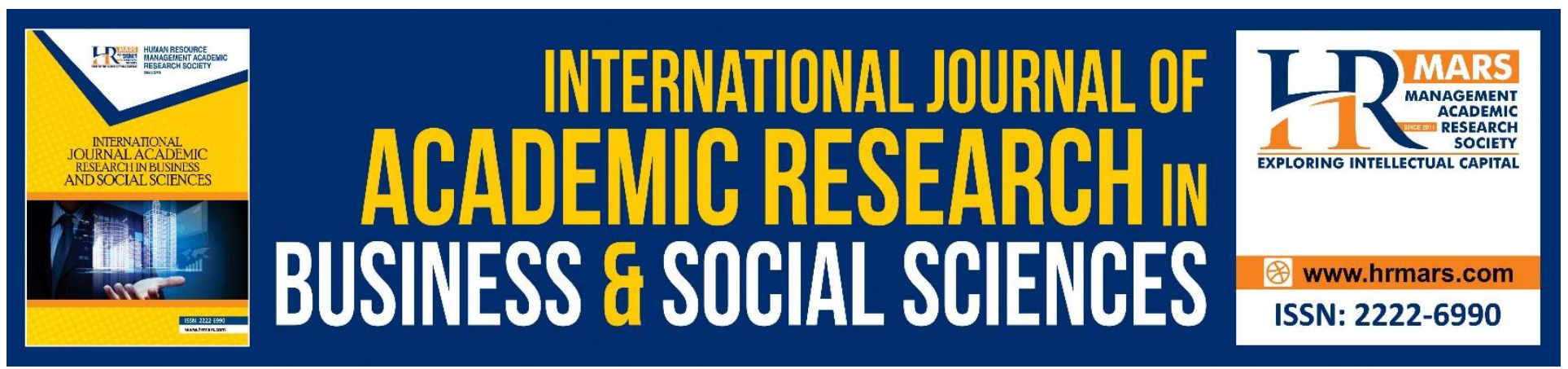

\title{
The Impact of Religiously Motivated Consumer Boycotts on Product Judgment, Brand Image and Loyalty
}

\author{
Farhan Mirza ${ }^{1}$, Sarfraz Ashraf ${ }^{2}$, Hafiz Badar Jahangir ${ }^{3}$ \\ ${ }^{1}$ KUBEAC Dept, University of Management and Technology, Sialkot Campus, ${ }^{2} \mathrm{MBA} / \mathrm{M}$.Phil. \\ Marketing, University of Sargodha, ${ }^{3}$ University of Punjab, Gujranwala Campus
}

Email: sarfrax.ashraf@gmail.com

\begin{abstract}
The publication of depicts of Prophet (PBUH) in January 2015 by a French magazine caused a boycott of French products in the Muslim world. Therefore, this study was designed to analyze the protesting behavior of Pakistani consumers regarding the purchase of French products. The religiously motivated boycott model was developed to examine the mediating effect of the boycott on product judgment, brand image, and loyalty. This study found that religious animosity has a substantial impact on boycotting French products but the boycott of French products does not have a substantial influence on the image and loyalty of French brands. Consistent with previous findings, our study suggests that product judgment is independent of religious animosity and boycott. This study has provided several implications to the manager of international organizations that are going to or already have entered in Muslim dominated markets. This study is concerned with the impact of the boycott of the religiously motivated consumer on brand image and loyalty. Furthermore, this study recommends that forthcoming researchers should on the influence of politically and economically motivated consumers on the brand image and loyalty with the brands.
\end{abstract}

Keywords: Boycott, Product Judgment, Brand Image, and Loyalty.

\section{Introduction}

Organizations put themselves in a large competition in order to manage the image of their brands (Abosag \& Farah, 2014). Despite these efforts and planning, a firm often finds itself involved in unanticipated, boycott-caused, marketing crises originated from a contentious event in which the organization has not any direct link (Ettenson \& Klein, 2005). While boycotting as a willful anticonsumption behavior has taken place for periods, customer groups are progressively following boycotts as their favorite powerful means of showing displeasure from targeted brands (Sen et al., 2001). As per The Economist (1995, p.15), it poses not be an evil thing for the customer to demand a superior degree of behavior from the companies whose products they are using. 
INTERNATIONAL JOURNAL OF ACADEMIC RESEARCH IN BUSINESS AND SOCIAL SCIENCES Vol. 10, No. 11, 2020, E-ISSN: 2222-6990 @ 2020 HRMARS

Various political, ethical, legal, and religious factors influence consumers' behavior. Boycott behavior is a part of consumer behavior where buying behaviors are prejudiced by ethical and social matters (Shimp \& Sharma, 1987; Riefler \& Diamantopoulos, 2007). A controversial political or religious event may cause a customer to contribute to a boycott campaign. A boycott is an effort to change or punish, by one or more parties, a firm's contentious act to attain certain objectives by encouraging individual consumers to forbear from purchasing specific products in the market (Friedman, 1985). These consumers are encouraged by non-governmental organizations and other pressure groups that are involved in protesting the firm's controversial actions (Klein et al., 2002). So, the boycott is that case of consumer purchase behavior in which purchase decision is influenced by ethical and social issues (Klein et al., 2004).

There are many reasons that marketing managers must have an understanding of the boycott phenomenon. The first reason is that the use of boycott as a tool for expressing anger is increasing (Friedman, 1991; Gelb, 1995; Sen et al., 2001). Second, customers are supporting the organizations which have an agenda on any political, social, or religious issues (Friedman, 1991, 1999; Gelb, 1995). The third reason is the threat consumer boycotts pose to the firm's regular marketing activities. Boycotts not only negatively affect a firm's sales (Miller \& Sturdivant, 1977), but also interrupt other marketing activities. The firms directed by a well-organized consumer boycott may not be able to prolong adequate customer focus (Klein et al., 2004). The price of the stock of boycotted firms may also be negatively affected due to even announcement of boycott (Pruitt \& Friedman, 1986). Boycotts also affect the morale of suppliers, employees, and other stakeholders of the boycotted firm (Barton, 1993; Pincus \& Acharya, 1988).

Various states and administrations are trying to prohibit the wearing of signs relating to a specific religion (Crumley, 2004). Furthermore, many issues are creating a political environment and are a major cause of political conflict among countries. Some of the issues include the 9/11 attacks and the Iraq war. In addition, Danish goods have also been boycotted by Muslim consumers because of a religious conflict caused by the publication of Prophet Muhammad depicts in a Danish newspaper (Knight, Mitchell, \& Gao, 2009). These cartoons were considered highly and intentionally offensive by many Muslims and were also regarded as a way to show the enmity of Europe towards Muslims (Knight et al., 2009). As a result of the boycott, the sale of the Danish company's products was decreased to zero within a few days. In the Middle East, the boycott of the famous Danish company Arla's products had cost the company about $€ 54$ million. These controversial events show the gap between Muslim countries and non-Muslim countries and the effect of cultural conflicts on the company's business (Willer, 2006).

The importance of religion has been recognized by researchers in the fields of sociology, psychology, and consumer behavior. Organizational behavior and political science have also been shown much interest in research on consumer boycotts (Ettenson \& Klein, 2005). However, less importance is given to cultural and religious issues as motivators to participate in the boycott campaign (Al-Hyari et al., 2012).

The purpose of this research is to investigate the behavior of Pakistani consumers regarding the purchase of French products after a controversial event on January 13, 2015. Charlie Hebdo, a French satirical magazine, published a depiction of the Muslim prophet Muhammad (PBUH) on the front cover of the magazine. The prophet sloughing a tear and holding a sign reading "Je Suis Charlie", is shown on the cover. This depiction on the cover was in kindness with the journalists killed during last week's attack on the magazine's Paris office (the guardian, 2015). On January 7, 2015, three 
INTERNATIONAL JOURNAL OF ACADEMIC RESEARCH IN BUSINESS AND SOCIAL SCIENCES Vol. 10, No. 11, 2020, E-ISSN: 2222-6990 @ 2020 HRMARS

masked gunmen attacked the Paris office of Charlie Hebdo and killed 12 people including two police officers, four cartoonists, and the editor of the magazine (BBC News, 2015). This attack was considered as the worst terrorist assail in France since 1961, followed by the magazine's publications of what was perceived as Prophet Muhammad's (PBUH) depicts (Dawn.com, 2015). The attackers also said that they took avenge for publishing Prophet's cartoons (China Topix, 2015).

The cover depict was drawn by Luz, one of the magazine's cartoonists, who survived the attack because of his late coming to the office. Charlie Hebdo, whose editor was not discouraged by death threats for drawings cartoon of Prophet Muhammad (PBUH) in a manner that caused anger to Muslims, frequently targets Prophet Muhammad by publishing He depicts and cartoons (the guardian, 2015).

The prior research studies have mainly addressed how consumer boycott can impact the product judgement and loyalty (Farah \& Newman, 2010). Similarly, Ashraf et al., (2018) has commented that consumer become loyal when they perceive that the organizations substantially emphasizing their priorities. However, the religiously motivated consumers have great intentions toward the organization. From this perspective, it can state that the literature is ambiguous regarding how religiously motivated consumer's boycott can predict product judgement, image and brand loyalty. Therefore, this study is designed to fill this gap by contributing to the literature. Though the contribution of this study will be religiously motivated consumers and boycott toward the organization.

\section{Literature Review \\ Conceptual Background}

The literature covers three research areas regarding consumer boycott. History reveals a steady increase in boycotts since the 1960s (Putnam, 1993; Economist, 1990). According to the results of the first wave of World Values Survey, conducted in 1982,16\% of the objects questioned in the United States had already taken part in boycotting campaigns and $35 \%$ of the objects indicated that they may boycott any company in the future. The results of the fourth wave, conducted in 2000, showed that $26 \%$ of the objects surveyed indicated boycott participation and $51 \%$ answered that they may participate in the future (Hoffmann \& Müller, 2009). According to Jackson and Schantz (1993), over 300 boycotts were configured and enforced in 1990. The increase in knowledge and expertise of boycott organizations in enforcing their boycott activities has caused an increase in the number of boycotts to over 800 (Fergeson, 1997).

There are two main types of boycotts regarding the motive of boycott, "instrumental and expressive" (Friedman, 1999). The motive of the instrumental boycott is to intimidate the target firm to change the controversial policy. The reason for the boycott is precisely and measurably described so that the target company may take corrective actions to satisfy the boycotters. The motive of the expressive boycott is to express the dissatisfaction of consumers with the target company's actions and to vent frustrations of boycotters (Friedman, 1999).

Boycotts possibly will also be characterized, based on target, as direct or indirect. In a direct boycott, consumers boycott the products of a particular company whose actions or policies are considered objectionable (Friedman, 1991, 1999; N. C. Smith \& Cooper-Martin, 1997; N. C. Smith, 1990). For example, in 1997, Muslims boycotted Nike's products because they claimed that the "Air" logo on the shoes resembles the word "Allah" in the Arabic script (American Thinker, 2012). In this case, the management of the target company must change its controversial action or policy. As in 
INTERNATIONAL JOURNAL OF ACADEMIC RESEARCH IN BUSINESS AND SOCIAL SCIENCES Vol. 10, No. 11, 2020, E-ISSN: 2222-6990 @ 2020 HRMARS

Nike's example, the company agreed to recall its $8,00,000$ shoes carrying the controversial logo (Bangor Daily News, 1997).

In an indirect boycott, the consumers refuse the use of a company's products not because of its controversial actions, but because of the actions of another party. In this case, products of a company are rejected just because of its relation to the offending party. The rationale of this boycott is that the loss of sales and image will induce the offending party to change its contentious policies or to apologize for its contentious actions (Friedman, 1991, 1999; Garrett, 1987). For example, Australian consumers boycotted French products because of French nuclear testing in the South Pacific in 1996 (Ettenson \& Klein, 2005). This example reveals that a company of a particular country may have to face a boycott of its products because of the controversial actions or policies of the Government. Because of not having direct access to the government of the offending country, consumers boycott the firms of the offending country, all products made in the offending country, and organizations having a relationship with that country (Ettenson \& Klein, 2005).

Consumer boycotts are increasing because they work (Klein et al., 2002), but it is hard to measure their rate of occurrence, magnitude, and impact because target firms do not release the strength and impact of boycotts on the decision-making process (Friedman, 1999). Boycotts relating to social issues are becoming more relevant for management as brand exposures are increasing and consumers are paying more attention to corporate social responsibility. Consumer groups with different beliefs, goals, and arguments organize boycotts that help in encouraging corporate social responsibility and controlling the social aspect of business (N. C. Smith, 1990).

\section{Motivations for Boycott Participation}

A boycott is considered effective if it causes a decline in the sale of the target company's products but it is different from the success of a boycott which lies in the achievement of boycott objectives (Smith, 1990). An unproductive boycott may cause a decrease in the sale of products of a boycotted firm and on the other hand, a boycott may be successful without causing a decrease in the sale of target firm's products. The goal of boycott should be an imposition on the target to change its controversial policy or apologize for its contentious action.

Consumer participation is one of the main factors which make a boycott effective (Smith, 1990). The value and importance of a boycott campaign and pressure on the target firm to respond to the boycott increases if a large number of consumers participate in the boycott. Consumer participation in a boycott makes a firm believe that its policy or action is controversial and it should amend that controversy. A large number of boycott participants also reveal that these consumers are not going to buy the products of the boycotted company in the future, causing a decrease in the sale of that company.

Boycott's contribution is not only a joined attempt for behavior change but also denotes a complicated sensitive manifestation of the individuality of each participant (Kozinets \& Handelman, 1998). Consumer's need for annoyance expression, for self-enhancement or maintenance, for consistency (Brewer and Brown, 1998) and his sensation of moral responsibility can be important to boycott motivators. Blasi and Oresick (1985) found that this sense of identity is expressed by morally responsible actions. The identity of a person who is devoted to a set of values becomes at risk if his manners are incompatible with these values. There may be a wrong assessment of the accurate association between one's involvement and the target's behavior (John \& Klein, 2003). The reasons for this attitude can be perceived effectiveness and illusion of control. Perceived effectiveness is the 
INTERNATIONAL JOURNAL OF ACADEMIC RESEARCH IN BUSINESS AND SOCIAL SCIENCES Vol. 10, No. 11, 2020, E-ISSN: 2222-6990 @ 2020 HRMARS

inflated evaluation of one's influence while the illusion of control is one's belief that others will behave by his actions (Farah \& Newman, 2010).

Studies of factors motivating consumers to participate or not to participate in a boycott trust on a cost and benefits approach and socio-psychological theories. Boycott's decision is described as a social issue by Sen et al. (2001) and consumers have to decide whether to participate in the boycott campaign in order to increase joint benefits or not to join to boost their benefits. This decision is dependent on various factors including inhibited consumption, the vulnerability of consumers to normative societal pressure, the perception that the boycott will be successful (Sen et al., 2001), cost of consumer's confidence, taste, and devotion to the target's product (John \& Klein, 2003), and lack of reasonable substitutes in the marketplace (Sen et al., 2001). It will take time for a consumer to find out a better substitute for a boycotted product, develop trust and confidence in the use of that substitute, and become brand loyal. Consumer's motivation to participate in the boycott is influenced by free-rider and small agent effects (Hardin, 1968; Olson, 1965). Some consumers believe that they would be benefited by boycott even if they would not participate in boycott and so they decide to be benefited from the contribution of others (Farah \& Newman, 2010). Many consumers' belief that they represent a relatively small portion of the market and their contribution will not produce a great impact is also a cause to restrain consumers from participating in the boycott. The assessment that the boycott campaign will not produce desired outcomes is also a factor limiting inspiration to participate. The free-rider and the small agent effect will vanish if some consumers, motivated by a flush of victory, decide to join a successful boycott campaign (Klein et al., 2004).

In addition to the cost and benefits approach, socio-psychological theories have also been integrated by researchers into the field of consumer boycott (Hoffmann \& Müller, 2009). Kozinets and Handelman (1998) found that consumers boycott not only for the sake of combined effect but also for achieving self-actualization and for the emotional manifestation of themselves. According to the AEB model (awareness-egregiousness-boycott), proposed by Klein et al. (2004), consumers must have awareness of the target's contentious action and must have egregiousness for that action. This sense of egregiousness leads to boycott participation.

\section{Conceptual Framework and Hypothesis Development Religious Animosity}

Consumer animosity can be defined as the "leftovers of hostility linked to earlier or current political, economical, military or diplomatic events, that will have a direct, negative effect on consumer's purchase behavior in the international market" (Ettenson \& Klein, 2005). It refers to robust adverse feelings regarding the purchase of products from a hated state or group of people. Most of the studies relating to consumer animosity have analyzed the boldness of the consumers of one country to the goods of another country (Rose et al., 2009). Animosity may have many sources, from a comparatively kind rivalry resulting from sharing an adjacent border to more severe expressions as a result of previous military actions or current political or economic disputes (Klein et al., 1998). Examples of consumer animosity include animosity of Jewish consumers toward purchasing German products, the attitude of Australian consumers towards French products (Ettenson \& Klein, 2005), boycott of Chinese products by American consumers (Witkowski, 2000), Dutch animosity towards German products (Nijssen \& Douglas, 2004), boycott of Danish products by Saudi Arabian consumers (Abosag \& F. Farah, 2014). If customers find an overseas nation causing damage to their own country, they will demonstrate animosity to that nation. Thus, animosity, based on emotions, shows the 
INTERNATIONAL JOURNAL OF ACADEMIC RESEARCH IN BUSINESS AND SOCIAL SCIENCES Vol. 10, No. 11, 2020, E-ISSN: 2222-6990 @ 2020 HRMARS

effects of international tensions on the relationship of citizens of different countries (Akdogan, Ozgener, Kaplan, \& Coskun, 2012). The likelihood that a country's contentious political, military or religious movements may cause animosity to the products manufactured by that country has actuated research studies regarding customers' animosity, its background, and its impact on consumer's buying behavior (Leong et al., 2008).

Religion has a substantial role in many facets of life including trade among the countries or war against each other. Anecdotal facts propose that religious animosity affects consumers' purchase intentions (Kalliny \& States, 1998). In Muslim dominant markets, it is a strong cause for consumer boycotts that are aggressively used by consumers to express their hate towards those governments and firms whose actions are considered as offensive to Muslims (Abd-Razak \& Abdul-Talib, 2012). According to religious leaders, it is the religious obligation of followers to boycott products of those foreign countries of which actions are religiously controversial (Kalliny \& States, 1998). In 2005, for example, Muslim leaders called Muslims to boycott Danish products due to publishing the cartoons of Prophet Muhammad by a Danish newspaper, Jyllands Posten (Riefler \& Diamantopoulos, 2007).

\section{Consumer Ethnocentrism}

Consumer ethnocentrism possibly will be defined as the "beliefs detained by consumers about the suitability and morality of purchasing foreign-made products". Ethnocentric customers have faith in that it is incorrect to buy imported goods because it harms the domestic economy and causes loss of jobs (Shimp \& Sharma, 1987). These beliefs are influenced by "surrounding groups" (Nijssen and Douglas, 2004), for example, customers' ethnocentrism provides a specific feeling of individuality and belonging (Shimp \& Sharma, 1987). Thus, it is expected that ethnocentric consumers are biased towards national products (Evanschitzky, v. Wangenheim, Woisetschläger, \& Blut, 2008). They will not accept symbols, values, and people that are culturally different and will feel pride and affection for intra-cultural objects (Herche, 1994).

\section{Consumer Ethnocentrism and Religious Animosity}

Consumer ethnocentrism and religious animosity are correlated but different from each other. Consumer ethnocentrism adds to the consumer's tendency to avoid purchasing foreign goods in general (Klein \& Ettensoe, 1999), though animosity is a country-specific construct (Nijssen \& Douglas, 2004). In the same way, we suggest the association amid "religious animosity and consumer ethnocentrism". It is also proposed that during a macro boycott, caused by the contentious act of a firm or government against a particular religion, ethnocentric consumers may have higher animosity against the culprit of the act (Abosag \& Farah, 2014). The study of Klein and Ettenson (1998) revealed that consumers with a low score on CETSCALE may accept to buy foreign goods in general but may reject to buy products from specific countries for which they have a sense of animosity. It means a consumer may purchase goods imported from different countries but not goods imported from a specific target country. If a customer does not find a domestic alternative of a particular product category, he might be willing to buy imported products of some countries even with a high score on the CAT SCALE but not of other particular countries (Klein et al., 1998). While studies of Klein and Ettenson (1999) and Rose et al. (2009) relate ethnocentrism and animosity, studies of Shankarmahesh (2006) conceive that animosity is the antecedent of consumer ethnocentrism. In this study, we contend that during macro-boycotts that are religiously motivated, consumer ethnocentrism, and animosity towards the target country are related. 
INTERNATIONAL JOURNAL OF ACADEMIC RESEARCH IN BUSINESS AND SOCIAL SCIENCES Vol. 10, No. 11, 2020, E-ISSN: 2222-6990 @ 2020 HRMARS

\section{Religious Animosity and Boycotting Behavior}

Consumers who have a sense of hostility to a state, caused by a connected religious crime, possibly will boycott the goods of its organizations (Klein et al., 1998). During their study on religious animosity, Ili-Salsabila and Abdul-Talib (2012) examined the connection of animosity in the Muslim markets with consumer boycotts and paid concentration to the primary causes behind consumer annoyance and hostility. Customers with high commitment to religious values not only consider vendors' sustenance of contentious reasons as incorrect, but also participate in boycott campaign to express their frustration in the marketplace (Swimberghe, Flurry, \& Parker, 2011; Iftikhar et al., 2017). Therefore, it leads to formulating the subsequent hypothesis:

H1: Religious animosity towards France increases Pakistani consumers' boycott of French products.

\section{Religious Animosity and Product Judgment}

Studies on country-of-origin (COO) have examined the effect of the country's image on consumer judgment of products manufactured by it (Johansson et al., 1985). These studies have focused on the ability of country-of-origin to form product judgment, measured in standings of superiority, reliability, value, and industrial development (Darling \& Arnold, 1988). Even though studies on country-of-origin suppose a straight relation amid "product judgment and consumer purchase behavior", the animosity framework proposes the "direct effect of consumer animosity on purchase behavior independent of product judgment" (Green \& Srinivasan, 1990). Furthermore, Klein et al. (1998) also demonstrated that hostility toward a specific bull's eye state is not related to a customer's assessment of a good's superiority. This outcome demonstrates that rage toward a target country doesn't need to lead to the defamation of product quality (Ettenson \& Klein, 2005). That is, due to the emotional state of animosity, consumers will not purchase the goods of a target country believing that it produces products of high quality (Ettenson \& Klein, 2005; Klein et al., 1998, 2002).

Contrasting previous results, Rose et al. (2009) and Shoham et al. (2006) found that animosity destructively exaggerated the valuation of product quality. From the perspective of our study, we propose that consumers will develop religious animosity against a country that is involved in a religiously contentious act. This sense of hostility possibly will be central to the boycott of goods formed by brands of offending country autonomously of goods judgment (Klein et al., 1998). Based on such arguments, we hypothesize:

H2: Religious animosity towards France negatively influences Pakistani consumers' judgment of French products.

\section{Consumer Ethnocentrism and Boycotting Behavior}

Consumer ethnocentrism adds to a customer's tendency to restrict purchasing imported goods in general and an inclination to position domestically produced products as superior in quality to products of international states (Klein \& Ettensoe, 1999). Besides, consumers who have feelings of enmity against a particular country may not purchase products of that country even if they are not ethnocentric (Klein et al., 1998). Research by Klein et al. (1998) and Shimp and Sahrma (1987) had stated that "consumer ethnocentrism" is destructively linked to the readiness to purchase imported goods. Therefore, we hypothesize that:

H3: Pakistani consumers' ethnocentrism increases their boycott of French products. 
INTERNATIONAL JOURNAL OF ACADEMIC RESEARCH IN BUSINESS AND SOCIAL SCIENCES Vol. 10, No. 11, 2020, E-ISSN: 2222-6990 @ 2020 HRMARS

\section{Consumer Ethnocentrism and Brand Loyalty}

One of the strategic objectives for most companies is the creation of customer loyalty because it resists the customers from switching to competitors (Akdogan et al., 2012). Loyalty is defined as the "consumer's intent to continue with an organization" (Zeithaml, Berry, \& Parasuraman, 1996). It is the function of supposed product superiority, trust, emotional bonding, social attachment, personal determination, and their cooperative properties (Ogba \& Tan, 2009). It depends on supportive gossip, a confrontation to swapping, recognition with the product, and a priority for a certain product seller amongst rivalry (Hwang \& Wen, 2009). It helps the organization in letting down buyer price compassion, diminishing spending on appealing to new customers; and improving profitability (Rowley, 2005).

Research suggests that highly ethnocentric consumers consider the domestically produced products as higher in quality than foreign-made products (Klein \& Ettenson, 1999) and are not likely to buy imported goods. However, if a domestic alternative of a brand is not available, consumers are likely to purchase a foreign brand even if they have an antagonistic attitude towards that brand (Nijssen \& Douglas, 2004). Since ethnocentric consumers give preference to domestic brands for their loyalty, it is expected that ethnocentric consumers will lose their loyalty towards a targeted foreign company during a boycotting movement (Abosag \& F. Farah, 2014). Keeping in view this argument, we hypothesize that:

H4: Pakistani consumers' ethnocentrism negatively influences their loyalty to French products.

\section{Consumer Efficacy and Boycotting Behavior}

Consumer efficacy is defined as the "belief by consumers that a boycott is a useful instrument to force a target to change a controversial policy" (Ettenson \& Klein, 2005). In the case of Pakistani customers and French products, it is supposed that Pakistani customers will take part in the "boycott of French products if they believe that it will change French attitudes" (Klein et al., 2004). Research on social problems proposes that collaboration changes in a straight line with customer's perceived efficacy, or the degree to which an individual believes that each contributor, including himself, can subsidize appreciably to the attainment of combined goals (Van Lange, Liebrand, Messick, \& Wilke, 1992). The literature proposes that those customers who are high in customer's efficacy i.e. who have faith in that their contribution to boycott campaign is likely to alter the action of the aberrant party are more probable to take part in a boycott than those who think that boycotts are not going to be fruitful in enforcing variation (Ettenson \& Klein, 2005). Thus, it can be proposed as the following:

H5: Consumer efficacy is positively related to Boycott's participation.

\section{Boycotting Behavior, Product Judgment, Customer Loyalty, and Brand Image}

Boycotts negatively affect brands from the target country, because customers will keep a further adverse image of the brands from the boycotted country (N. C. Smith \& Cooper-Martin, 1997). Consumers' confidence that a particular firm has involved in a wrong and harmful action is the common factors encouraging boycott participation (Klein et al., 2004; Ashraf et al., 2018). Smith and Cooper-Martin (1997) suggested that hostility affects the brand image, that is, a higher level of supposed egregiousness will more destructively distress the brand image. Different socialpsychological theories suggest that attempting an action normally heads to behavior-consistent attitudes. Thus, customer's boycotting results in the devaluation of their perception regarding the brand and quality of the products formed by the target company. A consumer who boycotts an 
INTERNATIONAL JOURNAL OF ACADEMIC RESEARCH IN BUSINESS AND SOCIAL SCIENCES Vol. 10, No. 11, 2020, E-ISSN: 2222-6990 @ 2020 HRMARS

overseas brand may relate the brand's image with the controversial action committed by that overseas country. Consequently, boycotters hold a negative image and a negative judgment of the goods manufactured by organizations of that nation (Abosag \& F. Farah, 2014). In the perception of the above discussion, we hypothesize that:

H6: The boycott of French products by Pakistani consumers negatively affects the French company's brand image.

Literature has revealed a big impact of global brands on goods awareness and judgment (Leclerc et al., 1994). The consumers who are charmed by global brands should find switching from these brands to be costly (M. Smith \& Li, 2010). While explaining the consequences of product judgment because of purchase behavior, Klein et al. (1998) and Shoham et al. (2006) reported that the perception of consumers about a product to be of better quality increases their willingness to buy that product. During their study, Abosag and F.Farah (2014) proposed that product judgment does not essentially central to an unwillingness to buy but during a boycott, the customer's refusal to buy possibly will negatively impact on customer's assessment of the boycotted goods. therefore, the following hypotheses have been formulated;

H7: The boycott of French products by Pakistani consumers negatively influences their judgment of French products.

Literature has provided ample evidence of global brands having a strong impact on customer loyalty (Zeithaml et al., 1996). However, if consumers have feelings of egregiousness towards a particular country that is involved in a controversial action and boycott the products of that country's firms will reduce their loyalty to the related brand (Abosag \& F. Farah, 2014). Thus, we hypothesize that:

H8: The boycott of French products by Pakistani consumers decreases their loyalty to the brand.

\section{Customer Loyalty, Brand Image and Customer's Judgment}

As discussed earlier, global brands can significantly impact both "product evaluation" (Leclerc et al., 1994) and "customer loyalty" (Zeithaml et al., 1996; Ashraf et al., 2017; 2018). Consumers in different countries consider global brands to further esteemed and of advanced superiority (Steenkamp et al., 2003), while insights diverge from culture to culture (Moore, McGowan Kennedy, \& Fairhurst, 2003; Sehar et al., 2019). The studies on the theme suggest that both states of production and image of brands have an imperative impact on consumer judgment of goods superiority (Aaker, 1997). Thus, we suppose that brand image positively impacts both product judgment and customer loyalty even throughout the boycott. Accordingly, we hypothesize that:

H9: French products' brand image increases Pakistani consumers' loyalty.

H10: French products' brand image positively influences Pakistani consumers' judgment of the French products. 
INTERNATIONAL JOURNAL OF ACADEMIC RESEARCH IN BUSINESS AND SOCIAL SCIENCES

Vol. 10, No. 11, 2020, E-ISSN: 2222-6990 @ 2020 HRMARS

Figure 1: Religiously Motivated Consumer Boycott Model

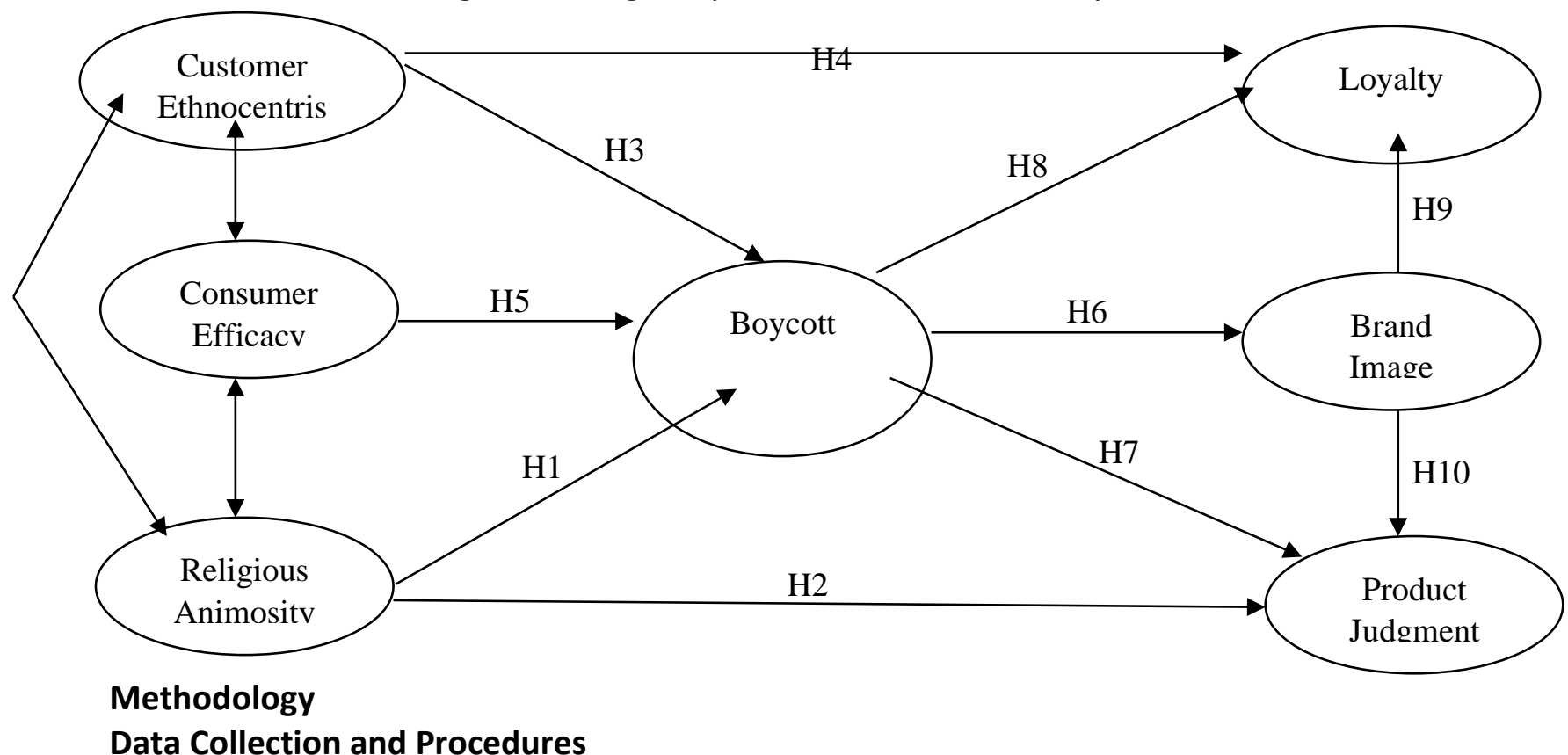

The research study was undertaken in the second half of 2019 on those Pakistani consumers who were familiar with French products. Data were collected in November 2019 using a convenience sampling technique from the consumers from various cities of Pakistan.

During the survey, researchers personally met respondents and requested them to complete the self-administrated questionnaire. Before completing the questionnaire, participants were first told the purpose of the research. Researchers explained to them that the study is conducted to examine the behavior of Pakistani customers regarding the purchase of French products just after the publication of depicts of Prophet (PBUH) by a French magazine. Participants were also informed about the French brands that are being used in Pakistan. These brands include Charlie, Calvin Klein, Do It, Youngs, One Man Show, and Exclusive. Furthermore, respondents were ensured that their responses will be strictly confidential and will only be used for academic purposes.

Of the potential respondents contacted, 460 agreed to participate. Out of these 460 questionnaires, 8 questionnaires contained missing responses and were not included in the process of data analysis, though analysis was carried with the sample of 452 responses. All respondents were Pakistani citizens consisting of $29.2 \%$ males and $70.8 \%$ females. Responses on education level indicated that $76.1 \%$ of the participants had a Masters or above degree.

\section{Survey Instrument and Measures}

Participants were requested to point out their level of agreement on a 7-point scale where $1=$ "strongly disagree" and 7 = "strongly agree". They were required to respond about statements relating to seven key constructs listed below:

i. Customer Ethnocentrism (Adopted from Rose et al., 2009)

ii. Consumer Efficacy (Adopted from Ettenson and Klein, 2005)

iii. Religious Animosity (Adopted from Klein et al., 1998)

iv. Boycotting Behavior (Adopted from Rose et al., 2009)

v. Loyalty (Adapted from Zeithmal et al., 1996) 
INTERNATIONAL JOURNAL OF ACADEMIC RESEARCH IN BUSINESS AND SOCIAL SCIENCES Vol. 10, No. 11, 2020, E-ISSN: 2222-6990 @ 2020 HRMARS

vi. Brand Image (Adapted from Martinez et al., 2008)

vii. Product Judgment (Adopted from Darling \& Wood, 1989; Darling \& Arnold, 1988)

\section{Results}

\section{Reliability and Validity}

The reliability of scales was tested using SPSS 17 . The results of the reliability test indicated that the value of Cronbach's alpha for all variables, except one (Customer Ethnocentrism=0.68), was higher than 0.70. According to Nunnally (1978), if Cronbach's alpha produces a value of 0.70, it will ensure that the internal consistency of the questionnaire is reliable.

The results of composite reliability and average variance extracted (AVE) indicate that the composite reliability of all the constructs is greater than the threshold value of 0.06 (Fornell \& Larcker, 1981). AVE for all the constructs (except product judgment $=0.498$ and consumer efficacy $=0.445$ ) is greater than the threshold value of 0.50 (Hair, Anderson, Tatham, \& Black, 1998) which represents that convergent validity significantly existed. Moreover, AVE is also greater than the shared variance for all the constructs (except product judgment and brand image) which significantly proved the discriminant validity of the collected data.

Table 1: Validity Measurement

\begin{tabular}{|l|l|l|l|l|l|}
\hline & CR & Cron. $\alpha$ & AVE & MSV & ASV \\
\hline Religious Animosity & 0.859 & 0.828 & 0.671 & 0.423 & 0.181 \\
\hline Product Judgement & 0.797 & 0.788 & 0.498 & 0.593 & 0.184 \\
\hline Brand Image & 0.779 & 0.774 & 0.543 & 0.593 & 0.212 \\
\hline Loyalty & 0.867 & 0.863 & 0.621 & 0.476 & 0.149 \\
\hline Boycott & 0.824 & 0.788 & 0.613 & 0.423 & 0.128 \\
\hline Consumer Efficacy & 0.705 & 0.705 & 0.445 & 0.266 & 0.128 \\
\hline Customer Ethnocentrism & 0.821 & 0.685 & 0.609 & 0.295 & 0.135 \\
\hline
\end{tabular}

To measure the fitness of the model, a structural equation model (SEM) was applied using AMOS 22. SEM allows the simultaneous assessment of a series of multiple regression equations that are separate and interdependent by itemizing the structural model applied by the statistical program (Hair et al., 2006). The results explored by the measurement model test (first part of SEM) demonstrate how properly the constructs are captured by their specified indicators (Bollen, 1989). The measurement model is a good fit in terms of statistical values. The value of chi-square is 2.79 which is lower than the maximum predefined value of 3 . The value of RMSEA is 0.07 which is also less than the maximum predefined or threshold value of 0.08 . furthermore, the values of GFI, CFI, TLI, and $\mathrm{NFI}$ are, $0.91,0.97,0.93$, and 0.92 respectively which are also greater than the threshold value of 0.9 . All of these statistical values indicating that the proposed model is a good fit in statistical terms.

\section{Correlation Analysis}

The correlation analysis is utilized to assess the kind of linkage amid two or more constructs. The following table indicating the correlation analysis of the studied constructs. The table representing that loyalty is positively related to the brand image and product judgment while it is negatively 
INTERNATIONAL JOURNAL OF ACADEMIC RESEARCH IN BUSINESS AND SOCIAL SCIENCES Vol. 10, No. 11, 2020, E-ISSN: 2222-6990 @ 2020 HRMARS

related to consumer efficacy, religious animosity, and customer ethnocentrism, further it has not substantially linked with the boycott. The brand image was found to be positively and substantially related to product judgment, consumer efficacy, consumer ethnocentrism, religious animosity, and boycott. Furthermore, the remaining paths were also found to be positively and substantially related to each other.

Table 2. Correlation Matrix

\begin{tabular}{|l|l|l|l|l|l|l|l|}
\hline Variables & 1 & 2 & 3 & 4 & 5 & 6 & 7 \\
\hline Loyalty & 1 & & & & & & \\
\hline Brand image & $.573^{* *}$ & 1 & & & & & \\
\hline Product Judgment & $.545^{* *}$ & $.610^{* *}$ & 1 & & & & \\
\hline Consumer Efficacy & -.052 & $.243^{* *}$ & .067 & 1 & & & \\
\hline Customer Ethnocentrism & -.040 & .052 & .020 & $.444^{* *}$ & 1 & & \\
\hline Religious Animosity & $-.101^{*}$ & $.177^{* *}$ & $.141^{* *}$ & $.394^{* *}$ & $.390^{* *}$ & 1 & \\
\hline boycott & .000 & .016 & .042 & $.214^{* *}$ & $.348^{* *}$ & $.535^{* *}$ & 1 \\
\hline$* * P<0.01$ level (2-tailed).
\end{tabular}

\section{SEM Analysis}

The following figure 2, represents the estimation of the model which have been picked from the SEM analysis using IBM Amos. The results indicated that loyalty is significantly impacted by customer ethnocentrism and brand image while it has an insignificant link with a boycott of the French products. Brand image and product judgment also insignificantly impacted by the boycott of the French products. Furthermore, the boycott of the French products was found to be significantly impacted by customer ethnocentrism and religious animosity while it is insignificantly impacted by consumer efficacy.

Figure 2: Model Estimation

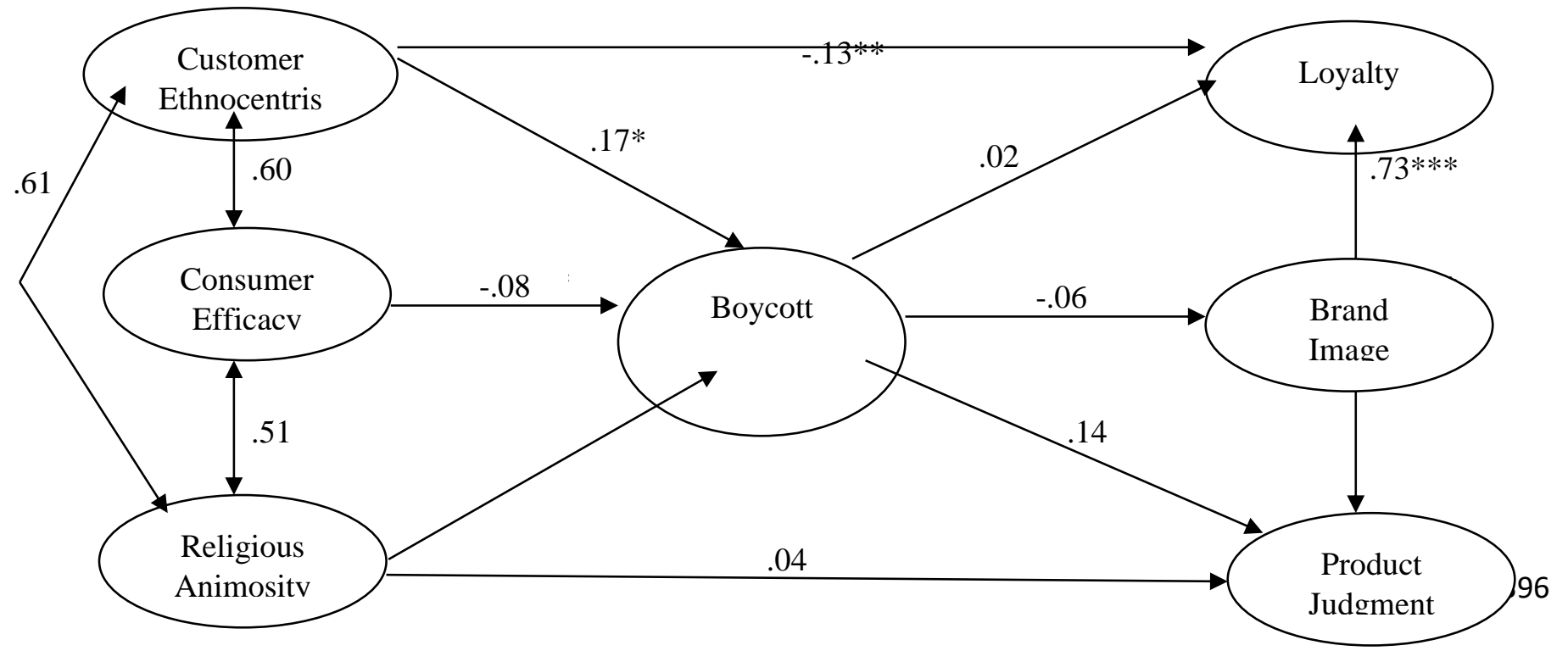


INTERNATIONAL JOURNAL OF ACADEMIC RESEARCH IN BUSINESS AND SOCIAL SCIENCES Vol. 10, No. 11, 2020, E-ISSN: 2222-6990 @ 2020 HRMARS

The following table demonstrates the summary of hypotheses, it can be seeming that out of atal of 10 hypotheses, 5 hypotheses have been supported by the statistical findings while the remaining 5 hypotheses have been rejected by the statistical findings.

Table: 3 Hypothesis Analyses

\begin{tabular}{|l|l|l|l|}
\hline S. \# & Description & $\mathbf{p}$-value & Decision \\
\hline H1: & Religious animosity $\rightarrow$ Boycott & $* * *$ & Accepted \\
\hline H2: & Religious animosity $\rightarrow$ Consumer Product Judgment & .546 & Rejected \\
\hline H3: & Consumer Ethnocentrism $\rightarrow$ Boycott & .028 & Accepted \\
\hline H4: & Consumer Ethnocentrism $\rightarrow$ Loyalty & .010 & Accepted \\
\hline H5: & Consumer efficacy $\rightarrow$ Boycott & .296 & Rejected \\
\hline H6: & Boycott $\rightarrow$ Brand Image & .255 & Rejected \\
\hline H7: & Boycott $\rightarrow$ Product Judgement & .128 & Rejected \\
\hline H8: & Boycott $\rightarrow$ Loyalty & .627 & Rejected \\
\hline H9: & Brand Image $\rightarrow$ Loyalty & $* * *$ & Accepted \\
\hline H10: & Brand Image $\rightarrow$ Consumer's Product Judgment & $* * *$ & Accepted \\
\hline
\end{tabular}

\section{Findings and Discussion}

Previous research has indicated that boycotts can induce an organization to correct its controversial action as its share price may negatively be affected due to boycott (Davidson, Worrell, \& El-Jelly, 1995; Pruitt \& Friedman, 1986). Studies of Abosag \& Farah (2014) suggested that consumer boycotts cause a decrease in the brand image of the target, but our studies indicate that boycott of French products does not have a substantial influence on image and loyalty of French brands. Due to the good quality and lack of suitable alternatives to French products, Pakistani customers are not indicating a decrease in their loyalty for French brands. However, customer ethnocentrism increases the happening of boycott and significantly causes a decrease in loyalty.

Moreover, religious animosity has a significant effect on boycotting French products but does not affect the judgment of the quality of French products. It means consumers perceive the French products as of good quality even having feelings of animosity towards France. Likewise, our test of the hypothesis that boycott negatively influences product judgment is found insignificant which shows that consumers do not deny the quality of French products even if they do not want to purchase them.

Contrary to our hypothesis that Consumer efficacy is positively related to Boycott participation, our study shows that consumer efficacy does not significantly affect boycott 
INTERNATIONAL JOURNAL OF ACADEMIC RESEARCH IN BUSINESS AND SOCIAL SCIENCES Vol. 10, No. 11, 2020, E-ISSN: 2222-6990 @ 2020 HRMARS

participation. It means Pakistani consumers are low on efficacy and they believe that France will not correct its contentious act event if they boycott the French products.

Furthermore, our studies found a substantial optimistic impact of brand image on brand loyalty and product judgment which supports our hypothesis that brand image increases consumers' loyalty and positively influences product judgment. If French brands have a strong position of the image in customers, then such customers will remain loyal to those brands and will consider that brands as of the best quality.

\section{Managerial Implications and Future Research}

When companies become the target of a macro boycott, it becomes difficult for these companies to select a suitable strategy to neutralize the boycott campaign. Following suggestions are available in this regard:

While customer ethnocentrism has a significant influence on boycott participation, companies need to keep them away from the cause of boycott that is the result of a contentious action by their country of origin. However, quick response to boycott from managers may help in reducing the impact of customer ethnocentrism.

The findings of this study indicate the religious animosity is the key cause to increase the boycott. Managers should be conscious of how boycotters interpreted the situation and should obtain arguments to counteract those interpretations.

As we find that boycott does not have a substantial impact on product judgment, brand image, and loyalty, managers of companies doing business in Pakistan do not need to worry about the negative product judgment and a decrease in brand image and loyalty.

Knudsen et al., (2008) suggested that organizations need to be ready at all times with an upto-date plan to tackle boycotts. However, before putting any of these plans into practice, the boycotted firm must have sufficient information about the cause of the boycott campaign so that it could make the right decision to neutralize the effects of the boycott.

As a result of the publication of cartoons by French magazine, French products were boycotted in Pakistan and other Muslim countries as well. But due to time and financial restrictions, other states were not encompassed in the study. Furthermore, forthcoming research studies could be conducted to test the same model in other Muslim countries where French products are being used. Further studies may also examine the influence of economically or politically motivated boycotts on brand image and loyalty.

\section{References}

Aaker, J. L. (1997). Dimensions of brand personality. Journal of Marketing Research, 347-356.

Abd-Razak, I.-S., \& Abdul-Talib, A.-N. (2012). Globality and intentionality attribution of animosity: An insight into the consumer boycotts in the Muslim dominant markets. Journal of Islamic Marketing, 3(1), 72-80.

Abosag, I., \& Farah, F. M. (2014). The influence of religiously motivated consumer boycotts on brand image, loyalty and product judgment. European Journal of Marketing, 48(11/12), 2262-2283.

Akdogan, M. S., Ozgener, S., Kaplan, M., \& Coskun, A. (2012). the Effects of Consumer Ethnocentrism and Consumer Animosity on the Re-Purchase Intent: the Moderating Role of Consumer Loyalty. EMAJ: Emerging Markets Journal, 1(1), 0-12. http://doi.org/10.5195/emaj.2012.15 
INTERNATIONAL JOURNAL OF ACADEMIC RESEARCH IN BUSINESS AND SOCIAL SCIENCES Vol. 10, No. 11, 2020, E-ISSN: 2222-6990 @ 2020 HRMARS

Al-Hyari, K., Alnsour, M., Al-Weshah, G., \& Haffar, M. (2012). Religious beliefs and consumer behaviour: from loyalty to boycotts. Journal of Islamic Marketing, 3(2), 155-174.

American Thinker (2012), "Muslim Outrage, Intimidation, and Blackmail".

Ashraf, S., Ilyas, R., Imtiaz, M., \& Tahir, H. M. (2017). Impact of CSR on customer loyalty: putting customer trust, customer identification, customer satisfaction and customer commitment into equation-a study on the banking sector of Pakistan. International Journal of Multidisciplinary and Current Research, 5(5), 1362-1372.

Ashraf, S., Iftikhar, A., Yameen, A., \& Younas, S. (2018). Empirical Relationship of Customer Brand Engagement with Satisfaction and Loyalty Through Online Brand Experience. IUP Journal of Brand Management, 15(3).

Ashraf, S., Ilyas, R., Imtiaz, M., \& Ahmad, S. (2018). Impact of service quality, corporate image and perceived value on brand loyalty with presence and absence of customer satisfaction: A study of four service sectors of Pakistan. Sciences, 8(2), 452-474.

Bangor Daily News. (1997), "Nike, Muslim group reach accord on logo".

Barton, L. (1993). Crisis in organizations: Managing and communicating in the heat of chaos: SouthWestern Pub. Co.

BBC News (2015), "Charlie Hebdo: Gun attack on French magazine kills 12".

Bollen, K. A. (1989). Structural equations with latent variables. Series in probability and mathematical statistics. New York, Wiley.

China Topix. (2015), "Charlie Hebdo Cover Angers Pakistani Militants, Draws Boycott of French Products".

Crumley, B. (2004), “After the head-scarf ban”, Time International (South Pacific Edition), No. 7, p. 40.

Darling, J. R., \& Arnold, D. R. (1988). The competitive position abroad of products and marketing practices of the United States, Japan, and selected European countries. Journal of Consumer Marketing, 5(4), 61-68.

Davidson, W. N., Worrell, D. L., \& El-Jelly, A. (1995). Influencing Managers to Change Unpopular Corporate Behavior through Boycotts and Divestitures A Stock Market Test. Business \& Society, 34(2), 171-196.

Dawn. (2015), "Charlie Hebdo publishes first cover since attack".

Ettenson, R., \& Klein, J. G. (2005). The fallout from French nuclear testing in the South Pacific: $A$ longitudinal study of consumer boycotts. International Marketing Review (Vol. 22). http://doi.org/10.1108/02651330510593278

Evanschitzky, H., Wangenheim, V. F., Woisetschläger, D., \& Blut, M. (2008). Consumer ethnocentrism in the German market. International Marketing Review, 25(1), 7-32.

Farah, M. F., \& Newman, A. J. (2010). Exploring consumer boycott intelligence using a socio-cognitive approach. Journal of Business Research, 63(4), 347-355.

Fornell, C., \& Larcker, D. F. (1981). Structural equation models with unobservable variables and measurement error: Algebra and statistics. Journal of Marketing Research, 382-388.

Friedman, M. (1985). Consumer boycotts in the United States, 1970-1980: Contemporary events in historical perspective. Journal of Consumer Affairs, 19(1), 96-117.

Friedman, M. (1991). Consumer boycotts: A conceptual framework and research agenda. Journal of Social Issues, 47(1), 149-168.

Friedman, M. (1999). Consumer boycotts: Effecting change through the marketplace and the media. Psychology Press. 
INTERNATIONAL JOURNAL OF ACADEMIC RESEARCH IN BUSINESS AND SOCIAL SCIENCES Vol. 10, No. 11, 2020, E-ISSN: 2222-6990 @ 2020 HRMARS

Garrett, D. E. (1987). The effectiveness of marketing policy boycotts: Environmental opposition to marketing. The Journal of Marketing, 46-57.

Gelb, B. D. (1995). More boycotts ahead? Some implications. Business Horizons, 38(2), 70-76.

Green, P. E., \& Srinivasan, V. (1990). Conjoint analysis in marketing: new developments with implications for research and practice. The Journal of Marketing, 3-19.

Hair, J. F., Anderson, R. E., Tatham, R. L., \& Black, W. C. (1998). Multivariate Data Analysis. New Jersey: Prentivce-Hall International. Inc.

Hair, J. F., Black, B., Babin, B., Anderson, R., and Tatham, R.L. (2006), Multivariate Data Analysis, Pearson International, New York, NY.

Hardin, G. (1968). The tragedy of the commons. Science, 162(3859), 1243-1248.

Herche, J. (1994). Ethnocentric tendencies, marketing strategy and import purchase behaviour. International Marketing Review, 11(3), 4-16.

Hoffmann, S., \& Müller, S. (2009). Consumer boycotts due to factory relocation. Journal of Business Research, 62(2), 239-247.

Hwang, J., \& Wen, L. (2009). The effect of perceived fairness toward hotel overbooking and compensation practices on customer loyalty. International Journal of Contemporary Hospitality Management, 21(6), 659-675.

Iftikhar, A., Azam, F., Ashraf, S., \& Tahir, H. M. (2017). Exploring the Relationship Between Religiosity, Brand Trust and Green Purchase Intention as a Catalyst of Attitude. Int. J. of Multidisciplinary and Current research, 5, 1485-1493.

Ili-Salsabila A., and Abdul-Talib, A. (2012), "Globality and intentionality attribution of animosity: An insight into the consumer boycotts in the Muslim dominant markets", Journal of Islamic Marketing, Vol. 3, No.: 1, pp.72-80.

Jackson, J. E., and Schantz, W. T. (1993), "Crisis management lessons: when push shoved Nike", Business Horizons, (January/February), pp. 27-35.

Johansson, J. K., Douglas, S. P., \& Nonaka, I. (1985). Assessing the impact of country of origin on product evaluations: a new methodological perspective. Journal of Marketing Research, 388396.

John, A., \& Klein, J. (2003). The boycott puzzle: consumer motivations for purchase sacrifice. Management Science, 49(9), 1196-1209.

Kalliny, M., \& States, U. (1998). Religious and cultural animosity model extension: implications for purchase intentions, 7-12.

Klein, J. G., \& Ettensoe, R. (1999). Consumer animosity and consumer ethnocentrism: An analysis of unique antecedents. Journal of International Consumer Marketing, 11(4), 5-24.

Klein, J. G., Ettenson, R., \& Morris, M. D. (1998). The Animosity Model of Foreign Product Purchase: An Empirical Test in the People's Republic of China. Journal of Marketing, 62(1), 89. http://doi.org/Doi 10.2307/1251805

Klein, J. G., Smith, N. C., \& John, A. (2002). Why we boycott: Consumer motivations for boycott participation and marketer responses. LONDON BUSINESS SCHOOL (June), 1-41.

Klein, J. G., Smith, N. C., \& John, A. (2004). Why we boycott: Consumer motivations for boycott participation. Journal of Marketing, 68(3), 92-109.

Knight, J. G., Mitchell, B. S., \& Gao, H. (2009). Riding out the Muhammad cartoons crisis: contrasting strategies and outcomes. Long Range Planning, 42(1), 6-22. 
INTERNATIONAL JOURNAL OF ACADEMIC RESEARCH IN BUSINESS AND SOCIAL SCIENCES

Vol. 10, No. 11, 2020, E-ISSN: 2222-6990 @ 2020 HRMARS

Knudsen, K., Aggarwal, P. and Maamoun, A. (2008), "The burden of identity: responding to product boycotts in the Middle East", Journal of Business \& Economics Research, Vol. 6, No. 11, pp. 17-25.

Kozinets, R. V, \& Handelman, J. (1998). Ensouling consumption: A netnographic exploration of the meaning of boycotting behavior. Advances in Consumer Research, 25(1), 475-480.

Leclerc, F., Schmitt, B. H., \& Dubé, L. (1994). Foreign branding and its effects on product perceptions and attitudes. Journal of Marketing Research, 263-270.

Leong, S. M., Cote, J. A., Ang, S. H., Tan, S. J., Jung, K., Kau, A. K., \& Pornpitakpan, C. (2008). Understanding consumer animosity in an international crisis: nature, antecedents, and consequences. Journal of International Business Studies, 39(6), 996-1009.

Miller, K. E., \& Sturdivant, F. D. (1977). Consumer responses to socially questionable corporate behavior: An empirical test. Journal of Consumer Research, 1-7.

Moore, M., McGowan Kennedy, K., \& Fairhurst, A. (2003). Cross-cultural equivalence of price perceptions between US and Polish consumers. International Journal of Retail \& Distribution Management, 31(5), 268-279.

Nijssen, E. J., \& Douglas, S. P. (2004). Examining the animosity model in a country with a high level of foreign trade. International Journal of Research in Marketing, 21(1), 23-38.

Nunnally, J. (1978), Psychometric Theory (McGraw-Hill, New York).

Ogba, I.-E., \& Tan, Z. (2009). Exploring the impact of brand image on customer loyalty and commitment in China. Journal of Technology Management in China, 4(2), 132-144.

Olson, M. (1965). The logic of collective action: Public goods and the theory of group. Harvard University Press Cambridge.

Pincus, J. D., \& Acharya, L. (1988). Employee communication strategies for organizational crises. Employee Responsibilities and Rights Journal, 1(3), 181-199.

Pruitt, S. W., \& Friedman, M. (1986). Determining the effectiveness of consumer boycotts: A stock price analysis of their impact on corporate targets. Journal of Consumer Policy, 9(4), 375-387.

Putnam Todd. Boycotts are busting out all over. Bus Soc Rev 1993;85:47-51.

Riefler, P., \& Diamantopoulos, A. (2007). Consumer animosity: a literature review and a reconsideration of its measurement. International Marketing Review, 24(1), 87-119.

Rose, M., Rose, G. M., \& Shoham, A. (2009). The impact of consumer animosity on attitudes towards foreign goods: a study of Jewish and Arab Israelis. Journal of Consumer Marketing, 26(5), 330339. http://doi.org/10.1108/07363760910976583

Rowley, J. (2005). The four Cs of customer loyalty. Marketing Intelligence \& Planning, 23(6), 574-581.

Sehar, R., Ashraf, S., \& Azam, F. (2019). The Influence of Social Media's Marketing Efforts on Brand Equity and Consumer Response. IUP Journal of Marketing Management, 18(2), 30-53.

Sen, S., Gürhan-Canli, Z., \& Morwitz, V. (2001). Withholding consumption: A social dilemma perspective on consumer boycotts. Journal of Consumer Research, 28(3), 399-417.

Shankarmahesh, M. (2006) "Consumer ethnocentrism: an integrative review of its antecedents and consequences", International Marketing Review, Vol. 23, No. 2, pp.146- 172.

Shimp, T., \& Sharma, S. (1987). Consumer Ethnocentrism: Construction and Validation of the CETSCALE. Journal of Marketing Research, 24(3), 280-289. http://doi.org/10.2307/3151638

Shoham, A., Davidow, M., Klein, J. G., and Ruvio, A. (2006), "Animosity on the home front: the intifada in Israel and its impact on consumer behavior", Journal of International Marketing, Vol. 14 No. 3, pp. 92-114. 
INTERNATIONAL JOURNAL OF ACADEMIC RESEARCH IN BUSINESS AND SOCIAL SCIENCES

Vol. 10, No. 11, 2020, E-ISSN: 2222-6990 @ 2020 HRMARS

Smith, M., \& Li, Q. (2010). The boycott model of foreign product purchase: an empirical test in China. Asian Review of Accounting, 18(2), 106-130. http://doi.org/10.1108/13217341011059381

Smith, N. C. (1990). Morality and the market: Consumer pressure for corporate responsibility. London: Rutledge.

Smith, N. C., \& Cooper-Martin, E. (1997). Ethics and target marketing: The role of product harm and consumer vulnerability. The Journal of Marketing, 1-20.

Steenkamp, J.-B. E. M., Batra, R., \& Alden, D. L. (2003). How perceived brand globalness creates brand value. Journal of International Business Studies, 34(1), 53-65.

Swimberghe, K., Flurry, L. A., \& Parker, J. M. (2011). Consumer religiosity: Consequences for consumer activism in the United States. Journal of Business Ethics, 103(3), 453-467.

The Economist. (1990), "Boycotting Corporate America," The Economist May 26, pp. 69-70.

The Economist. (1995), "Saints and Sinners," The Economist June 24, pp. 15-16.

Theguardian. (2015), "Charlie Hebdo: first cover since terror attack depicts Prophet Muhammad".

Van Lange, P. A. M., Liebrand, W. B. G., Messick, D. M., \& Wilke, H. A. M. (1992). Social dilemmas: The state of the art. Social Dilemmas: Theoretical Issues and Research Findings, 3-28.

Willer, R. K. (2006). Dispelling the Myth of a Global Consumer: Indonesian Consumer Behavior Researched by Means of an Analytical Diagram for Intercultural Marketing; with a Case Study of Sunsilk Shampoo for the Veiled Woman.

Witkowski, T. (2000). Effects of animosity toward China on willingness to buy Chinese products. Managing in a Turbulent International Business Environment, 18, 470-477.

Zeithaml, V. A., Berry, L. L., \& Parasuraman, A. (1996). The behavioral consequences of service quality. The Journal of Marketing, 31-46. 